\title{
Is Innocence Irrelevant? Collateral Attack on Criminal Judgments
}

\author{
Henry J. Friendly†
}

Legal history has many instances where a remedy initially serving a felt need has expanded bit by bit, without much thought being given to any single step, until it has assumed an aspect so different from its origin as to demand reappraisal-agonizing or not. That, in my view, is what has happened with respect to collateral attack on criminal convictions. After trial, conviction, sentence, appeal, affirmance, and denial of certiorari by the Supreme Court, in proceedings where the defendant had the assistance of counsel at every step, the criminal process, in Winston Churchill's phrase, has not reached the end, or even the beginning of the end, but only the end of the beginning. Any murmur of dissatisfaction with this situation provokes immediate incantation of the Great Writ, with the inevitable initial capitals, often accompanied by a suggestion that the objector is the sort of person who would cheerfully desecrate the Ark of the Covenant. My thesis is that, with a few important exceptions, convictions should be subject to collateral attack only when the prisoner supplements his constitutional plea with a colorable claim of innocence.

If there be fear that merely listening to such a proposal may contaminate, let me attempt to establish respectability by quoting two statements of Mr. Justice Black:

... the defendant's guilt or innocence is at least one of the vital considerations in determining whether collateral relief should be available to a convicted defendant. ${ }^{1}$

And more strongly:

In collateral attacks ... I I would always require that the convicted defendant raise the kind of constitutional claim that casts some shadow of a doubt on his guilt. ${ }^{2}$

† Judge, United States Court of Appeals for the Second Circuit. This article was presented as the 1970 Ernst Freund lecture at the University of Chicago Law School. It constituted a revision of the Gifford lecture given in April, 1970, at the Syracuse University Law School.

1 Kaufman v. United States, 394 U.S. 217, 235-86 (1969) (dissenting opinion).

2 Id. at 242. 
Incredibly, these statements were made in dissent. Even more incredibly, the two other dissenting Justices expressed qualms about them. ${ }^{3}$ I believe, with qualifications I will elaborate, that this position ought to be the law and that legislation can and should make it so. When I speak of legislation, I am thinking mainly of federal habeas corpus for state prisoners and its equivalent for federal prisoners, since no other course seems realistic in light of Supreme Court opinions. In many states it may still be possible to reach the proper result by judicial decision. Although, if past experience is any guide, $I$ am sure I will be accused of proposing to abolish habeas corpus, my aim is rather to restore the Great Writ to its deservedly high estate and rescue it from the disrepute invited by current excesses.

Seventeen years ago, in his concurring opinion in Brown v. Allen," Mr. Justice Jackson expressed deep concern over the "floods of stale, frivolous and repetitious petitions [for federal habeas corpus by state prisoners which] inundate the docket of the lower courts and swell our own." The inundation consisted of 541 such petitions. In 1969, state prisoners filed 7,359 petitions for habeas corpus in the federal district courts, a 100 per cent increase over $1964 . .^{5}$ Federal prisoners filed 2,817 petitions challenging convictions or sentences, a 50 per cent increase over $1964 .^{\circ}$ Prisoner petitions, including those attacking the

3 Id. at 242 (dissenting opinion of Harlan, J., speaking also for Stewart, J.).

The conflict between Justice Black and his brethren on this score surfaced again in Wade v. Wilson, 396 U.S. 282 (1970). The majority was there concerned with "a question of first impression," namely, whether the Constitution requires a state to provide an indigent prisoner with a transcript of his eight-year-old trial so that he may "comb the record in the hope of discovering some flaw," 390 F.2d 632, 634 (9th Cir. 1968), although he had previously had access to a transcript and his request for a new one made no claim that any error actually existed. Reversing a decision of the court of appeals directing denial of the petition, the majority instructed the district court to hold the case in the hope that somehow a transcript might become available and the supposedly serious constitutional issue might thus be avoided. Justice Black thought the writ should be dismissed as improvidently granted, stating:

This case is but another of the multitudinous instances in which courts are asked interminably to hash and rehash points that have already been determined after full deliberation and review. One considered appeal is enough, in the absence of factors which show a possibility that a substantial injustice has been inflicted on the defendant.

396 U.S. at 289.

1344 U.S. 443, 532, 536 \& n.8 (1953).

- 1969 ANN. REP. OF THE DIRECTOR OF THE ADMinistRATIVE OFFICE OF THE UNITED STATES COURTS 144 [hereinafter cited as 1969 ANNUAL REPORT]. The most recent figures available, those for the third quarter of fiscal 1970, show a $19 \%$ increase over the same quarter of 1969. 1969 ANNUAL. REPORT Fig. D.

B Id. The increase is to be contrasted with the declining number of federal convictions and the rather static number of incarcerations in substantially the same period. administrative Office of the United States Courts, Federal Offenders in the United 
conduct of prison officials, totalled 12,924. These "comprise the largest single element in the civil caseload of the district courts" and "accounted for more than one-sixth of the civil filings." There has been a corresponding increase in the load imposed by post-conviction petitions upon the federal courts of appeals. Despite the safeguard intended to be afforded by the requirement of a certificate of probable cause, ${ }^{8}$ there were over twice as many appeals by state prisoners in 1969 as there were petitions in 1952.0 A similar explosion of collateral attack has occurred in the courts of many of the states. If 541 annual petitions for federal habeas corpus by state prisoners were an "inundation," what is the right word for 7,500 ? $^{10}$

STATES District CourTs 5-8, 30-37 (1970). There was a further increase of $20 \%$ in the third quarter of 1970 over the corresponding quarter of 1969. 1969 ANNUAL REPORT Fig. D.

71969 ANNUAL REPORT 141.

828 U.S.C. § 2253 (1964).

- In 1969, collateral attacks by state prisoners accounted for 1197 appeals and by federal prisoners for 591 . These comprised more than $20 \%$ of all appeals from district courts. See 1969 ANNUAL REPORT 196-97. It is not generally realized to what extent the courts of appeals are becoming criminal courts. The combination of the two categories cited and direct criminal appeals amounted to $50 \%$ of all appeals from the district courts.

For most circuits the state prisoner figures do not include unsuccessful applications by state prisoners for the issuance of certificates of probable cause. On the other hand, they do include cases where the district court has issued a certificate and, under Nowakowski v. Maroney, 386 U.S. 542 (1967), the court of appeals has been obliged to hear the appeal although it believed the certificate was improvidently issued. See Garrison v. Patterson, 391 U.S. 464, 465-67 (1968). In view of the staggering growth in the case loads of the courts of appeals and prospective further increases as the ratio of criminal appeals to convictions after trial approaches $100 \%$ (see Carrington, Crowded Dockets and the Courts of Appeals: The Threat to the Function of Review and the National Law, 82 Harv. L. REv. 542, 578 (1969)), Congress should move promptly to amend 28 U.S.C. \$ 2253 (1964) so as to place the authority to issue certificates of probable cause solely in the courts of appeals and require similar authorization for appeals by federal prisoners in cases under 28 U.S.C. § 2255 (1964) and FED. R. CRIM. P. 35. This is the opposite of the solution proposed in an elaborate 240-page Note, Developments in the Law-Federal Habeas Corpus, 83 HARv. L. REv. 1038, 1195 (1970) [hereinafter cited as Developments Note]. While the authors profess concern over "the time spent on deciding whether to issue a certificate," any judge could have told them how small this is as compared to the time spent in hearing an appeal and the burden on assigned counsel of having to argue a hopeless case. The Note suggests that "appeals courts can institute summary procedures if the burden of petitions is too great." Why not the existing "summary procedure" for screening out hopeless cases by requiring applications for a certificate, which are carefully processed for the judges by well-trained clerks assigned for the purpose?

10 The Developments Note, supra note 9, at 1041 seeks to minimize the burden on the basis that in 1968 "[m] ost of the petitions were quickly dismissed" since less than 500 "reached the hearing stage"-meaning a trial of the petition. The conclusion does not follow at all: a petition may require large expenditure of time by district and circuit judges even though no evidentiary hearing is held. Furthermore, the ability of the federal courts to dispense with evidentiary hearings in a large proportion of the state prisoner petitions is due in considerable measure to state post-conviction trials, and my concern is with the total burden. 
The proverbial man from Mars would surely think we must consider our system of criminal justice terribly bad if we are willing to tolerate such efforts at undoing judgments of conviction. He would be surprised, I should suppose, to be told both that it never was really bad and that it has been steadily improving, particularly because of the Supreme Court's decision that an accused, whatever his financial means, is entitled to the assistance of counsel at every critical stage. ${ }^{11} \mathrm{His}$ astonishment would grow when we told him that the one thing almost never suggested on collateral attack is that the prisoner was innocent of the crime. ${ }^{12}$ His surprise would mount when he learned that collateral attack on a criminal conviction by a court of general jurisdiction is almost unknown in the country that gave us the writ of habeas corpus and has been long admired for its fair treatment of accused persons. ${ }^{13}$ With all this, and with the American Bar Association having proposed standards relating to post-conviction

11 Gideon v. Wainwright, 372 U.S. 335 (1962) (trials); Doughty v. Maxwell, 376 U.S. 202 (1964) (guilty pleas); Douglas v. California, 372 U.S. 353 (1963) (appeals).

12 Chief Justice Burger has recently spoken to this point:

In some of these multiple trial and appeal cases the accused continued his warfare with society for eight, nine, ten years and more. In one case more than sixty jurors and alternates were involved in five trials, a dozen trial judges heard an array of motions and presided over these trials; more than thirty different lawyers participated either as court-appointed counsel or prosecutors and in all more than fifty appellate judges reviewed the case on appeals.

I tried to calculate the costs of all this for one criminal act and the ultimate conviction. The best estimates could not be very accurate, but they added up to a quarter of a million dollars. The tragic aspect was the waste and futility, since every lawyer, every judge and every juror was fully convinced of defendant's guilt from the beginning to the end.

Address before the Association of the Bar of the City of New York, N.Y.L.J., Feb. 19, 1970, at 1; 25 Record of N.Y.C.B.A. 14, 15-16 (Supp. 1970). Along the same lines Justice Schaefer of Illinois remarked at a conference of the Center for the Study of Democratic Institutions in June, 1968:

What bothers me is that almost never do we have a genuine issue of guilt or innocence today. The system has so changed that what we are doing in the courtroom is trying the conduct of the police and that of the prosecutor all along the line. Has there been a misstep at this point? At that point? You know very well that the man is quilty; there is no doubt about the proof. But you must ask, for example: Was there something technically wrong with the arrest? You're always trying something irrelevant. The case is determined on something that really hasn't anything to do with guilt or innocence. To the extent you are doing that to preserve other significant values, $I$ think it is unobjectionable and must be accepted. But with a great many derailing factors there is either no moral justification or only a very minimal justification.

13 Three cases a century apart, Ex parte Lees, 120 Eng. Rep. 718 (Q.B. 1860); Re Featherstone, [1953] 37 Crim. App. 146; and Re Corke, [1954] 1 W.L.R. 899, sufficiently illustrate the unawareness by the English courts of the extensive "common-law powers of the habeas judge," discovered in the extensive obiter in Fay v. Noia, 372 U.S. 391, 416 n.27 (1963). See Oaks, Legal History in the High Court-Habeas Corpus, 64 MicH. L. REv. $451,452-56,461-68$ (1966). The safeguard lies in exercise of the royal prerogative by the Home Secretary, who can at any time refer a petition to the Court of Appeal if he wishes judicial aid. See Criminal Appeal Act 1968, c. 19, $\$ 17$. 
remedies ${ }^{14}$ which, despite some kind words about finality, in effect largely repudiate it, the time is ripe for reflection on the right road for the future.

I wish to emphasize at the outset that my chief concern is about the basic principle of collateral attack, rather than with the special problem of federal relief for state prisoners which has absorbed so much attention since Brown v. Allen. I must therefore make my main analysis in the context of a unitary system. My model will be designed for our only pure example of a unitary structure, the federal system when dealing with federal convictions. Later I shall advocate adoption of the same model by the states for their much larger number of prisoners and of corresponding changes with respect to federal habeas for state prisoners. I shall conclude by showing that these proposals are wholly consistent with the Constitution.

For many reasons, collateral attack on criminal convictions carries a serious burden of justification.

First, as Professor Bator has written, "it is essential to the educational and deterrent functions of the criminal law that we be able to say that one violating that law will swiftly and certainly become subject to punishment, just punishment."15 It is not an answer that a convicted defendant generally remains in prison while collateral attack is pending. Unbounded willingness to entertain attacks on convictions must interfere with at least one aim of punishment-"a realization by the convict that he is justly subject to sanction, that he stands in need of rehabilitation." This process can hardly begin "if society continuously tells the convict that he may not be justly subject to reeducation and treatment in the first place."16 Neither is it an adequate answer that repentance and rehabilitation may be thought unlikely in many of today's prisons. That is a separate and serious problem, demanding our best thought ${ }^{17}$ but irrelevant to the issue here.

$A$ second set of difficulties arises from the fact that under our

14 ABA Standards Relating to Post-Conviction Remedies [hereinafter cited as ABA REPORT]. The Tentative Draft, issued in January, 1967, was approved by the House of Delegates in February, 1968.

15 Bator, Finality in Criminal Law and Federal Habeas Corpus for State Prisoners, 76 HaRv. L. Rev. 441, 452 (1963) [hereinafter cited as Bator], an article from which I have drawn heavily. See also Amsterdam, Search, Seizure and Section 2255: A Comment, 112 U. PA. L. Rev. 378, 387 (1964) [hereinafter cited as Amsterdam]; President's Commission

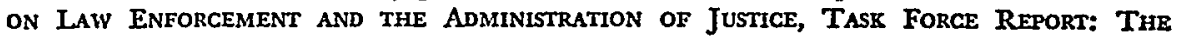
COURTS $45-47$ (1967).

16 Bator, supra note 15 , at 452 .

17 See the address of Chief Justice Burger referred to in note 12 supra. 
present system collateral attack may be long delayed-in habeas corpus as long as the custody endures, ${ }^{18}$ in federal coram nobis forever. ${ }^{19}$ The longer the delay, the less the reliability of the determination of any factual issue giving rise to the attack. ${ }^{20} \mathrm{It}$ is chimerical to suppose that police officers can remember what warnings they gave a particular suspect ten years ago, although the prisoner will claim to remember very well. Moreover, although successful attack usually entitles the prisoner only to a retrial, a long delay makes this a matter of theory only.21 Inability to try the prisoner is even more likely in the case of collateral attack on convictions after guilty pleas, since there will be no transcript of testimony of witnesses who are no longer available.22 Although the longer the attack has been postponed, the larger the proportion of the sentence that will have been served, we must assume that the entire sentence was warranted..$^{23}$ The argument against this,

18 This is an understatement. The Supreme Court has held that if habeas corpus is begun during custody, subsequent release does not moot the case. Carafas v. LaVallee, 391 U.S. 234 (1968). See also Jones v. Cunningham, 371 U.S. 286 (1963), allowing a petition to be brought by a prisoner released on parole, and United States ex rel. Di Rienzo v. New Jersey, 423 F $2 d 224$ (9d Cir. 1970), allowing habeas corpus when the sentence had been completed but it was possible that time could be credited on a second sentence being served.

19 United States v. Morgan, 346 U.S. 502 (1954).

20 Note Mr. Justice Douglas' recent statement in Illinois v. Allen, 397 U.S. 337, 351 (1970) (concurring opinion), that while "elapse of time is not necessarily a barrier to a challenge of the constitutionality of a criminal conviction . . . in this case it should be."

21 See Peyton v. Rowe, 391 U.S. 59, 62-63 (1968), and Judge Wyzanski's comment in Geagan v. Gavin, 181 F. Supp. 466, 469 (D. Mass. 1960), aff'd, 292 F.2d 244 (1st Cir. 1961), cert. denied, 370 U.S. 903 (1962).

22 Although the decision in MfcMann v. Richardson, 397 U.S. 759 (1970), wards off the worst threats with respect to collateral attack on convictions after guilty pleas, others remain. The Court expressly did not decide whether federal habeas will lie where state statutes, such as N.Y. CodE Crim. Proc. \$§ $813 \mathrm{a}$ and $813 \mathrm{~g}$, allow appeals from convictions on pleas of guilty following adverse decisions on motions to suppress evidence alleged to have been illegally seized or a confession claimed to have been unlawfully obtained, as held in United States ex rel. Rogers v. Warden, 381 F.2d 209 (2d Cir. 1967), and United States ex rel. Molloy v. Follette, 391 F.2d 23I (2d Cir.), cert. denied, 391 U.S. 917 (1968). At the very least there should be a requirement that federal habeas be instituted promptly after conclusion of the state appeal.

23 When the sentence has bcen fully served, it is almost certain that the state will not bother with a retrial. See United States v. Keogh, 391 F.2d 138, 148 (2d Cir. 1968). Successful collateral attack, very likely on a ground having no bearing on guilt, thus will mean wiping out the conviction of a guilty man. See, e.g., United States ex rel. Scanlon v. LaVallee, 2d Cir. 1970, in which a prisoner who had admitted guilt sought habeas corpus after completing his sentence because his lawyer allegedly had misinformed him of how long this might be. Such cases pointedly raise the question whether the only goal served by post-sentence collateral attack, namely, eradicating civil disabilities and social stigma, warrants the effort expended on the many attacks that fail and the likelihood of an essential unjust result in the few that succeed. See Hewett v. North Carolina, 415 F.sd 1316, 1325-26 (4th Cir. 1969) (Haynsworth, C.J., concurring). Certainly these would 
that only a handful of prisoners gain release, whether absolute or conditional, by post-conviction remedies, is essentially self-defeating, ${ }^{24}$ even if it is factually correct. To such extent as accurate figures might indicate the problem of release to have been exaggerated, they would also show what a gigantic waste of effort collateral attack has come to be. A remedy that produces no result in the overwhelming majority of cases, apparently well over ninety per cent, an unjust one to the state in much of the exceedingly small minority, and a truly good one only rarely, ${ }^{25}$ would seem to need reconsideration with a view to caring for the unusual case of the innocent man without being burdened by so much dross in the process.

Indeed, the most serious single evil with today's proliferation of collateral attack is its drain upon the resources of the communityjudges, prosecutors, and attorneys appointed to aid the accused, and even of that oft overlooked necessity, courtrooms. Today of all times we should be conscious of the falsity of the bland assumption that these are in endless supply. ${ }^{26}$ Everyone concerned with the criminal process, whether his interest is with the prosecution, with the defense, or with neither, agrees that our greatest single problem is the long delay in bringing accused persons to trial. ${ }^{2 \pi}$ The time of judges, pros-

be prime cases for requiring a colorable showing of innocence save in most exceptional instances.

24 Developments Note, supra note 9, at 1041. The basis for this assertion is that the federal courts released only 125 state prisoners in fiscal 1964 as against 3220 petitions filed, and that 350 reported district court decisions in 1968 showed outright releases of only 14 and remands of 25 to state courts for retrial or release. These figures do not take account of prisoners released by the states or under 28 U.S.C. $\$ 2255$ (1964). Wright and Sofaer regard the federal figures as showing a number of releases of state prisoners, about $4 \%$ of the cases, that is "surprisingly high." They cite a few examples where federal habeas unquestionably served a good purpose. Wright \& Sofaer, Federal Habeas Corpus for State Prisoners: The Allocation of Fact-Finding Responsibility, 75 YaLE L.J. 895, 899 \& nn.15 \& 16 (1966).

25 Accepting the figure of $4 \%$ absolute or conditional release in federal habcas for state prisoners, we lack information as to what happened on a retrial. On the assumption that half were again convicted, this leaves only $2 \%$ of the petitioners who benefited. Here again we do not know how many of these cases represented prisoners "whom society has grievously wronged and for whom belated liberation is little enough compensation," Fay v. Noia, 372 U.S. 391, 440-41 (1963), or how many were black with guilt. The assumption that many of them fall in the former category is wholly unsupported.

26 The Supreme Court in another context has recently adverted to "scarce judicial and prosecutorial resources" and has emphasized the desirability of conserving these "for those cases in which there is a substantial issue of the defendant's guilt or in which there is substantial doubt that the State can sustain its burden of proof." Brady $v$. United States, 397 U.S. 742, 752 (1970).

27 See Report of the President's Commission on Crime in the District of Columibia 255-56 (1966); REPORT OF THE PREsident's CoMmission on LAW ENFoRCEMENT AND AdMiNISTRATION of JUSTICE 154 (1967). Excluding cases involving defendants who are fugitives or in the armed forces, $16.9 \%$ of all criminal cases in the United States district courts 
ecutors, and lawyers now devoted to collateral attacks, most of them frivolous, would be much better spent in trying cases. To say we must provide fully for both has a virtuous sound but ignores the finite amount of funds available in the face of competing demands.

A fourth consideration is Justice Jackson's never refuted observation that "[i]t must prejudice the occasional meritorious application to be buried in a flood of worthless ones."28 The thought may be distasteful but no judge can honestly deny it is real.

Finally, there is the point which, as Professor Bator says, is "difficult to formulate because so easily twisted into an expression of mere complacency." 29 This is the human desire that things must sometime come to an end. Mr. Justice Harlan has put it as well as anyone:

Both the individual criminal defendant and society have an interest in insuring that there will at some point be the certainty that comes with an end to litigation, and that attention will ultimately be focused not on whether a conviction was free from error but rather on whether the prisoner can be restored to a useful place in the community. ${ }^{30}$

Beyond this, it is difficult to urge public respect for the judgments of criminal courts in one breath and to countenance free reopening of them in the next. I say "free" because, as I will later show, the limitation of collateral attack to "constitutional" grounds has become almost meaningless.

These five objections are not at all answered by the Supreme Court's conclusory pronouncement: "Conventional notions of finality of litigation have no place where life or liberty is at stake and infringement of constitutional rights is alleged." 31 Why do they have no place? One will readily agree that "where life or liberty is at stake," different rules should govern the determination of guilt than when only property is at issue: The prosecution must establish guilt beyond a reasonable doubt, the jury must be unanimous, the defendant need not testify, and so on. The defendant must also have a full and fair opportunity

have been pending for more than a year-in many districts the figure is much higher. 1969 ANNual Report, supra note 5, at 270-72. At the end of 1968, New York City had a non-traffic criminal backlog of more than 520,000 cases, 177,000 of which involved defendants who could no longer be located. NEw York Citr Criminar Justice INFormation bureau, The New York City Criminal Court: Case flow and Congestion from 1959 To 1968, 12-13. It seems likely that the average delay between indictment and trial is at least a year.

28 Brown v. Allen, 344 U.S. 443,537 (1953).

29 Bator, supra note 15 , at 452.

30 Sanders v. United States, 373 U.S. 1, 24-25 (1963) (dissenting opinion).

31 Id. at 8. 
to show an infringement of constitutional rights by the prosecution even though his guilt is clear. I would agree that even when he has had all this at trial and on appeal, "[t]he policy against incarcerating or executing an innocent man ... should far outweigh the desired termination of litigation." 32 But this shows only that "conventional notions of finality" should not have as much place in criminal as in civil litigation, not that they should have none. A statement like that just quoted, entirely sound with respect to a man who is or may be innocent, is readily metamorphosed into broader ones, such as the Supreme Court's pronouncement mentioned above, ${ }^{33}$ expansive enough to cover a man steeped in guilt who attacks his conviction years later because of some technical error by the police that was or could have been considered at his trial.

Admittedly, reforms such as I am about to propose might not immediately meet some of these points. Aside from the most drastic measures, ${ }^{34}$ changes that would narrow the grounds available for collateral attack would not necessarily discourage prisoners from trying; they have everything to gain and nothing to lose. Indeed, collateral attack may have become so much a way of prison life as to have created its own self-generating force: it may now be considered merely something done as a matter of course during long incarceration. Today's growing number of prisoner petitions despite the minute percentage granted points that way. But I would hope that over a period of time the trend could be reversed, although the immediate response might be less than dramatic. Furthermore, a requirement that, with certain exceptions, an applicant for habeas corpus must make a colorable showing of innocence would enable courts of first instance to screen out rather rapidly a great multitude of applications not deserving their attention and devote their time to those few where injustice may have been done, and would effect an even greater reduction in the burden on appellate courts. In any event, if we are dissatisfied with

32 Note, Federal Habeas Corpus Review of State Convictions: An Interplay of Appellate Ambiguity and District Court Discretion, 68 YALE L.J. 98, 101 n.13 (1958).

33 Another example is Professor Pollak's statement that "where personal liberty is involved, a democratic society employs a different arithmetic and insists that it is less important to reach an unshakable decision than to do justice." Pollak, Proposals to Curtail Habeas Corpus for State Prisoners: Collateral Attack on the Great Writ, 66 YALE L.J. 50, 65 (1956). Valid though this is when there is some question of an innocent man languishing in prison, why does "justice" require repeated opportunities to litigate issues of police or prosecutorial misconduct having no bearing on guilt? Does not Chief Justice Ellsworth's statement, "But, surely, it cannot be deemed a denial of justice, that a man shall not be permitted to try his case two or three times over," Wiscart v. D'Auchy, 3 U.S. (3 Dall.) 320, 328 (1796), have some application in criminal cases?

34 For example, a statute of limitations on the availability of collateral attack. 
the present efflorescence of collateral attack on criminal convictions and yet are as unwilling as I am to outlaw it and rely, as in England, solely on executive clemency, ${ }^{35}$ it is important to consider reform. If mine is not the best mousetrap, perhaps it may lead others to develop a better one.

\section{II}

Broadly speaking, the original sphere for collateral attack on a conviction was where the tribunal lacked jurisdiction either in the usual sense ${ }^{36}$ or because the statute under which the defendant had been prosecuted was unconstitutional ${ }^{37}$ or because the sentence was one the court could not lawfully impose. ${ }^{38}$ Thirty years ago, in approving the use of habeas corpus to invalidate a federal conviction where the defendant had lacked the assistance of counsel, Mr. Justice Black was careful to kiss the jurisdictional book. ${ }^{39} \mathrm{He}$ said that although the court may indeed have had "jurisdiction" at the beginning of the trial, this could be lost "due to failure to complete the court" as the sixth amendment was thought to require..$^{40}$

Many of the most famous and salutary uses of habeas can be fitted under this rubric. Moore $v$. Dempsey ${ }^{41}$ was clearly such a case, and insofar as Brown v. Allen and its companion case, Speller $v$. Allen, ${ }^{42}$ dealt with racial discrimination in the selection of the jury, they also could be considered as such. Claims that a jury was subjected to improper influences by a court officer ${ }^{43}$ or had been overcome by excessive publicity ${ }^{44}$ are also of this sort. In such cases the criminal process itself has broken down; the defendant has not had the kind of trial the Constitution guarantees. To be sure, there remains a ques-

35 However, it is amazing how far current discussions ignore this possibility of relief. One wonders whether some lawyers assigned to represent habeas petitioners may not be more interested in establishing a point than in getting their clients out of jail. See, in this connection, the comment in Fortas, Thurman Arnold and the Theatre of the Law, 79 YALE L.J. 988, 995 (1970). On the other side, I am always surprised at the willingness of prosecutors to let hard cases get to the Supreme Court rather than prevent the making of bad law by recommending clemency at an early stage. See Fay v. Noia, 372 U.S. 391, 476 n.28 (1963) (Harlan, J., dissenting).

36 Ex parte Watkins, 28 U.S. (3 Pet.) 193 (1830).

37 Ex parte Siebold, 100 U.S. 371 (1879). See Amsterdam, supra note 15, at 384 \& n.30. This, of course, is quite consistent with a view that the prime objective of collateral attack should be to protect the innocent.

88 Ex parte Lange, 85 U.S. (18 Wall.) 163 (1873).

89 Johnson v. Zerbst, 304 U.S. 458 (1938).

$40 \mathrm{Id}$. at 468 .

41261 U.S. 86 (1923).

42344 U.S. 443 (1953).

43 Parker v. Gladden, 385 U.S. 363 (1966).

14 Sheppard v. Maxwell, 384 U.S. 333 (1966). 
tion why, if the issue could have been raised on appeal and either was not or was decided adversely, the defendant should have a further opportunity to air it. ${ }^{45} \mathrm{Still}$, in these cases where the attack concerns the very basis of the criminal process, few would object to allowing collateral attack regardless of the defendant's probable guilt. These cases would include all those in which the defendant claims he was without counsel to whom he was constitutionally entitled. This need not rest on Justice Black's "jurisdictional" approach. For, as Justice Schaefer of Illinois has so wisely said, "Of all the rights that an accused person has, the right to be represented by counsel is by far the most pervasive, for it affects his ability to assert any other rights he may have."46

Another area in which collateral attack is readily justified irrespective of any question of innocence is where a denial of constitutional rights is claimed on the basis of facts. which "are dehors the record and their effect on the judgment was not open to consideration and review on appeal." 47 The original judgment is claimed to have been perverted, and collateral attack is the only avenue for the defendant to vindicate his rights. Examples are convictions on pleas of guilty obtained by improper means, ${ }^{48}$ or on evidence known to the prosecution to be perjured, ${ }^{49}$ or where it later appears that the defendant was incompetent to stand trial..$^{50}$

A third justifiable area for collateral attack irrespective of innocence is where the state has failed to provide proper procedure for making a defense at trial and on appeal. The paradigm is Jackson $v$.

45 See Bator, supra note 15 , at 457.

46 Schaefer, Federalism and State Criminal Trials, 70 HARv. L. REv. I, 8 (1956).

I would not be inclined to apply the same rule of automatic entitlement to collateral attack to all cases where the claim is lack of effective assistance of counsel-a claim that is bound to be raised ever more frequently as claims of total lack of counsel diminish in the course of time. I would assimilate cases where the state is alleged to have prevented counsel from doing his job-for example, by forcing him to trial without adequate opportunity for preparation, as in Powell v. Alabama, 287 U.S. 45 (1932)-to those where counsel was not provided at all. It is tempting to extend this principle to other cases where the ineffectiveness of counsel is flagrant and apparent. But the difficulty of drawing a line between such cases and the more frequent claims of ineffectiveness by hindsight would lead me to place all these in the category where a colorable showing of innocence should be required.

47 Waley v. Johnston, 316 U.S. 101, 104-05 (1942) (coerced plea of guilty).

48 Id.; Herman v. Claudy, 350 U.S. 116 (1956).

49 Mooney v. Holohan, 294 U.S. 103 (1935), where, however, the Court declined to issue the writ because it was not convinced of the absence of corrective process in the California state courts; Miller v. Pate, 386 U.S. 1 (1967). It should be clear that a case like the last, one of the glories of federal habeas corpus for state prisoners, remains wholly untouched by my proposal.

50 Pate v. Robinson, 383 U.S. 375 (1966). 
Denno, ${ }^{51}$ allowing collateral attack by federal habeas corpus on all New York convictions where the voluntariness of a confession had been submitted to the jury without a prior determination by the judge. Whether the case called for the retroactive remedy imposed may be debatable; in my view, the former New York procedure, although surely inferior to that prescribed by the Supreme Court, was a long way from being so shocking that it demanded the hundreds of state coram nobis and federal habeas corpus proceedings for past convictions which Jackson spawned. ${ }^{52}$ Still, one can hardly quarrel with the proposition that if a state does not afford a proper way of raising a constitutional defense at trial, it must afford one thereafter, and this without a colorable showing of innocence by the defendant.

New constitutional developments relating to criminal procedure are another special case. The American Bar Association Report says that these produce a growing pressure for post-conviction remedies. ${ }^{53}$ But here the Supreme Court itself has given us the lead. In only a few instances has it determined that its decisions shall be fully retroactive-the right to counsel, Jackson $v$. Denno, equal protection claims, ${ }^{54}$ the sixth amendment right to confrontation, ${ }^{55}$ and double jeopardy. ${ }^{50}$ In most cases the Court has ruled that its new constitutional decisions concerning criminal procedure need not be made available for collateral attack on earlier convictions. These include the extension to the states of the exclusionary rule with respect to illegally seized evidence, ${ }^{57}$ the prohibition of comment on a defendant's failure to take the stand, ${ }^{58}$ the rules concerning interrogation of per-

51378 U.S. 368 (1964).

52 Some such second thoughts may be detected in the majority opinion in McMrann v. Richardson, 397 U.S. 759, 771-74 (1970), by the writer of Jackson $v$. Denno.

53 ABA REPoRr, supra note 14, at 1. Professor Bator's 1963 belief that "[i]t is not fanciful to suppose that the law of due process for criminal defendants will, in the foreseeable future, reach a resting point, will become stabilized," proved an exceedingly poor prediction. Bator, supra note 15 , at 523-24.

54 Eskridge v. Washington Prison Bd., 357 U.S. 214 (1958), with respect to Griffin v. Illinois, 351 U.S. 12 (1956) (free transcript on appeal); Daegele v. Kansas, 375 U.S. 1 (1963), with respect to Douglas v. California, 372 U.S. 353 (1963) (right to counsel on appeal).

55 Roberts v. Russell, 392 U.S. 293 (1968), with respect to Bruton v. United States, 391 U.S. 123 (1968); Berger v. California, 393 U.S. 314 (1969), with respect to Barber v. Page, 390 U.S. 719 (1968).

56 North Carolina v. Pearce, 395 U.S. 711 (1969), with respect to Benton v. Maryland, 395 U.S. 784 (1969).

57 Linkletter v. Walker, 381 U.S. 618 (1965), with respect to Mapp v. Ohio, 367 U.S. 643 (1961).

58 Tehan v. Schott, 382 U.S. 406 (1966), with respect to Griffin v. California, 380 U.S. 609 (1965). 
sons in custody, ${ }^{69}$ the right to a jury trial in state criminal cases, ${ }^{60}$ the requirement of counsel at line-ups, ${ }^{61}$ and the application of the fourth amendment to non-trespassory wiretapping. ${ }^{62}$ While neither a state nor the United States is bound to limit collateral attack on the basis of a new constitutional rule of criminal procedure to what the Supreme Court holds to be demanded, I see no occasion to be holier than the pope.

None of these four important but limited lines of decision supports the broad proposition that collateral attack should always be open for the asserted denial of a "constitutional" right, even though this was or could have been litigated in the criminal trial and on appeal. The belief that it should stems mainly from the Supreme Court's construction of the Habeas Corpus Act of $1867^{63}$ and its successors, ${ }^{64}$ providing that the writ may issue "in all cases where any person may be restrained of his or her liberty in violation of the constitution, or of any treaty or law of the United States." Despite this language no one supposes that a person who is confined, after a proper trial, may mount a collateral attack because the court has misinterpreted a law of the United States; ${ }^{65}$ indeed the Supreme Court has explicitly decided the contrary even where the error was as apparent as could be. ${ }^{68}$ In such instances we are content that "conventional notions of finality" should keep an innocent man in prison unless, as one would hope, executive clemency releases him.

As a matter of the ordinary reading of language, it is hard to see how the result can be different when a constitutional claim has been rejected, allegedly in error, after thoroughly constitutional proceedings, and the history does not suggest that the statute was so intended. ${ }^{67}$ The reason why the Supreme Court did so construe the

59 Johnson v. New Jersey, 384 U.S. 719 (1966), with respect to Escobedo v. Illinois, 378 U.S. 478 (1964), and Miranda v. Arizona, 384 U.S. 436 (1966).

60 DeStefano v. Woods, 392 U.S. 631 (1968), with respect to Duncan v. Louisiana, 391 U.S. 145 (1968).

61 Stovall v. Denno, 388 U.S. 293 (1967), with respect to United States v. Wade, 388 U.S. 218 (1967), and Gilbert v. California, 388 U.S. 263 (1967).

62 Desist v. United States, 394 U.S. 244 (1969), with respect to Katz v. United States, 389 U.S. 347 (1967).

6314 Stat. 385 (1867).

6428 U.S.C. $\S \S 2241,2254,2255$ (1964).

65 See H.M. Hart \& H. Whchsler, The Federat Courts and the Federal System 1238 (1953): "There is a sense, therefore, in which a prisoner is legally detained if he is held pursuant to the judgment or decision of a competent tribunal or authority, even though the decision to detain rested on an error of law or fact."

66 Sunal v. Large, 332 U.S. 174 (1947).

67 See Mayers, The.Habeas Corpus Act of 1867: The Supreme Court as Legal Historian, 33 U. Crr. L. REv. 31 (1965); Geagan v. Gavin, 181 F. Supp. 466, 468 (1960). 
Act in Brown $\%$. Allen ${ }^{68}$ was, I believe, its consciousness that, with the growth of the country and the attendant increase in the Court's business, it could no longer perform its historic function of correcting constitutional error in criminal cases by review of judgments of state courts and had to summon the inferior federal judges to its aid.99 Once it was held that state prisoners could maintain proceedings in the federal courts to attack convictions for constitutional error after full and fair proceedings in the state courts, it was hard to read the same statutory words as meaning less for federal prisoners, even though the policy considerations were quite different. ${ }^{70}$ And once all this was decided, it was easy to slide into the belief that the states should, or even must, similarly expand their own procedures for collateral attack.

With a commentator's ability to consider policy free from imprisonment by statutory language, I perceive no general principle mandating a second round of attacks simply because the alleged error is a "constitutional" one. We have been conclusorily told there is "an institutional need for a separate proceeding-one insulated from inquiry into the guilt or innocence of the defendant and designed specifically to protect constitutional rights." 71 No empirical data is cited to support this, and so far as concerns proceeding within the same system, it seems fanciful. The supposition that the judge who has overlooked or disparaged constitutional contentions presented on pre-trial motions to suppress evidence or in the course of trial will avidly entertain claims of his own error after completion of the trial and a guilty verdict defies common sense. ${ }^{72}$

The dimensions of the problem of collateral attack today are a consequence of two developments. ${ }^{73}$ One has been the Supreme Court's imposition of the rules of the fourth, fifth, sixth and eighth amendments concerning unreasonable searches and seizures, double jeopardy, speedy trial, compulsory self-incrimination, jury trial in

08344 U.S. 443 (1953).

69 See the excellent statement of this point of view by Judge Wyzanski in Geagan v. Gavin, 181 F. Supp. 466, 469 (1960). See also Wright \& Sofaer, supra note 24, at 897-99.

70 See the discussion in Kaufman v. United States, 394 U.S. 217, 224-26 (1969). The Kaufman decision, although not the opinion, can be defended on this basis.

71 Developments Note, supra note 9, at 1057.

72 See Kitch, The Supreme Court's Code of Criminal Procedure: 1968-1969 Edition, 1969 Sup. CT. REv. 155, 182-83. The Developments Note later concedes, at 1059, that "[i]n many cases, the interests described above in a second proceeding can be filled by appellate review" and "[p]erhaps, then, only when appellate review is inadequate-for example because the appeals court cannot look beyond the record-should collateral attack be available." Why not, indeed?

73 This was forecast by Judge Wyzanski a decade ago in Geagan v. Gavin, 181 F. Supp. 466,469 (1960). 
criminal cases, confrontation of adverse witnesses, assistance of counsel, and cruel and unusual punishments, upon state criminal trials. The other has been a tendency to read these provisions with ever increasing breadth. The Bill of Rights, as I warned in 1965, has become a detailed Code of Criminal Procedure, ${ }^{74}$ to which a new chapter is added every year. The result of these two developments has been a vast expansion of the claims of error in criminal cases for which a resourceful defense lawyer can find a constitutional basis.

Any claimed violation of the hearsay rule is now regularly presented not as a mere trial error but as an infringement of the sixth amendment right to confrontation. ${ }^{75}$ Denial of adequate opportunity for impeachment would seem as much a violation of the confrontation clause as other restrictions on cross-examination have been held to be. $^{76}$ Refusal to give the name and address of an informer can be cast as a denial of the sixth amendment's guarantee of "compulsory process for obtaining witnesses." Inflammatory summations or an erroneous charge on the prosecution's burden of proof ${ }^{77}$ become denials of due process. So are errors in identification procedures. ${ }^{78}$ Instructing a deadlocked jury of its duty to attempt to reach a ver$\operatorname{dict}^{79}$ or undue participation by the judge in the examination of witnesses can be characterized as violations of the sixth amendment right to a jury trial. Examples could readily be multiplied. Today it is the rare criminal appeal that does not involve a "constitutional" claim.

I am not now concerned with the merits of these decisions which, whether right or wrong, have become part of our way of life. What I do challenge is the assumption that simply because a claim can be characterized as "constitutional," it should necessarily constitute a basis for collateral attack when there has been fair opportunity to litigate it at trial and on appeal. Whatever may have been true when the Bill of Rights was read to protect a state criminal defendant only if the state had acted in a manner "repugnant to the conscience of mankind,"80 the rule prevailing when Brown $v$. Allen was decided, the "constitutional" label no longer assists in appraising how far so-

74 H.J. Friendly, The Bill of Rights as a Code of Criminal Procedure, in Benchmarks 235 (1967).

75 This is true despite the holding in California v. Green, 399 U.S. 149 (1970), that the confrontation clause and the hearsay rule are not wholly congruent in scope.

70 Smith v. Illinois, 390 U.S. 129 (1968).

77 Cf. In re Winship, 397 U.S. 358 (1970).

78 Stovall v. Denno, 388 U.S. 293 (1967); Simmons v. United States, 390 U.S. 377 (1968);

Foster v. California, 394 U.S. 440 (1969).

79 Allen v. United States, 164 U.S. 492, 501 (1896).

80 Palko v. Connecticut, 302 U.S. 319, 325 (1937). 
ciety should go in permitting relitigation of criminal convictions. It carries a connotation of outrage-the mob-dominated jury, the confession extorted by the rack, the defendant deprived of counselwhich is wholly misplaced when, for example, the claim is a pardonable but allegedly mistaken belief that probable cause existed for an arrest or that a statement by a person not available for cross-examination came within an exception to the hearsay rule. A judge's overly broad construction of a penal statute can be much more harmful to a defendant than unwarranted refusal to compel a prosecution witness on some peripheral element of the case to reveal his address. ${ }^{81}$ If a second round on the former is not permitted, and no one suggests it should be, I see no justification for one on the latter in the absence of a colorable showing of innocence.

It defies good sense to say that after government has afforded a defendant every means to avoid conviction, not only on the merits but by preventing the prosecution from utilizing probative evidence obtained in violation of his constitutional rights, he is entitled to repeat engagements directed to issues of the latter type even though his guilt is patent. A rule recognizing this would go a long way toward halting the "inundation;" it would permit the speedy elimination of most of the petitions that are hopeless on the facts and the law, themselves a great preponderance of the total, and of others where, because of previous opportunity to litigate the point, release of a guilty man is not required in the interest of justice even though he might have escaped deserved punishment in the first instance with a brighter lawyer or a different judge.

\section{III}

This is an appropriate place to consider how far the recent ABA Report on Post-Conviction Review helps toward achieving what I think is the proper result. I submit it works in exactly the wrong direction.

A reader taking only a casual look at the Report might regard it as going a long way in the direction of promoting finality. The Introduction proclaims:

81 While the "harmless error" rule of Chapman v. California, 386 U.S. 18 (1967), and Harrington v. California, 395 U.S. 250 (1969), affords relief against constitutional claims on immaterial points, the test on collateral attack generally should be not whether the error could have affected the result but whether it could have caused the punishment of an innocent man. Note, Harmless Constitutional Error: A Reappraisal, 83 HARV. L. REv. 814 (1970), fails to distinguish between the problem on direct appeal and on collateral attack. 
A general principle underlying these standards is that once an issue of fact or law has been finally determined, that adjudication ought to be final and binding. ${ }^{82}$

Section 6.1 states: "Unless otherwise required in the interest of justice, any grounds for post-conviction relief as set forth in section 2.1 which have been fully and finally litigated in the proceedings leading to the judgment of conviction should not be relitigated in post-conviction proceedings." 83 However, what would otherwise be the salutary effect of this is largely destroyed by the definition, $\$ 6.1$ (a) (ii), that a question has been "fully and finally litigated" only "when the highest court of the state to which a defendant can appeal as of right has ruled on the merits of the question." If, for example, the defendant did not appeal because his lawyer thought that the trial court was correct or that any error would be found immaterial or that he would be convicted on a retrial, the issue remains open for collateral attack under the ABA draft unless there has been what is called an "abuse of process." Moreover, absent "abuse of process," claims that might have been but were not raised even in the trial court also remain open. The "abuse of process" exception, $\S 6.1(\mathrm{c})$, is put in terms of "deliberately and inexcusably" failing to pursue the point. While we are not told exactly what these adverbs mean, they clearly refer to something considerably beyond a negligent or even a considered decision not to utilize an available remedy; the state does not bring itself within them even by showing a deliberate failure simpliciter but must demonstrate "a deliberate failure to present an issue with an intention to present it later." 84

Save for the rare instance when the state is known to have evidence to refute a claim which it may not have later, it is exceedingly hard to visualize a case where a defendant or his lawyer would deliberately lay aside a meritorious claim so as to raise it after the defendant was jailed. It is even more difficult to imagine how the state could ever prove this. But if these are the only cases in which collateral attack is precluded by failure to raise a claim or to appeal from its denial, the ABA Report, while professing devotion to finality, would in fact work a wholesale repudiation of it. ${ }^{85}$ The explanation, in a somewhat different context, that "since the inquiry required to establish abuse of process is far more burdensome than that required to determine

82 ABA REPORT, supra note 14 , at 3.

83 Id. at 85 .

$84 I d$. at 88 (emphasis added).

85 This is hardly surprising since the Reporter, Professor Curtis Reitz, has long been an enthusiastic advocate of collateral attack. See the articles cited in note 126 infra. 
the validity of the claim, and since most applications do not present valid claims, it is simpler and more expeditious to reach the merits of claims before consideration of any suggestions of abuse of process," 86 does not explain at all. The high proportion of invalid claims would seem rather to be a reason for imposing measures to protect the courts from the heavy burden of considering them, ${ }^{87}$ and "the inquiry required to establish abuse of process" is "burdensome" only because the Report gives the term a meaning all its own.

Meaningful discussion of the preclusive effect of failing to raise a point at trial or pursue an appeal has been bedevilled by the concept of waiver. "Waiver" has been well said to be "a troublesome term in the law." 88 The ABA Report concedes that "[t]he term is subject to multiple meanings or shades of meanings which can result in confusion in communication and, perhaps, in thought." 80 Not only they can, they do. The initial and still the most cited use of this concept in the field with which we are here concerned, that by $\mathrm{Mr}$. Justice Black in Johnson $v$. Zerbst, ${ }^{90}$ was wholly appropriate. The sixth amendment, as he read it, required the provision of counsel; none had been provided; therefore the writ should issue unless the defendant had waived his right. Similar considerations are applicable to coercive interrogation or illegal search. The Constitution protects against compelled self-incrimination; thus an incriminating statement made under compulsion cannot be used over timely objection unless before answering the defendant had waived his privilege not to speak. It protects also against unreasonable searches; if there has been a search of a home without a warrant, the fruits thus cannot be used over objection unless the defendant has consented to the search. But it is a serious confusion of thought to transpose this

86 ABA REPORT, supra note 14 , at 36.

87 One item in the ABA Report which $I$ applaud is the inclusion as a ground of collateral attack "that there exists evidence of material facts, not theretofore presented and heard, which require vacation of the conviction or sentence in the interest of justice," id. \$ 2.1 (a)(iv), at 32, if this were limited, as it obviously should be, to facts which could not have been presented in the exercise of due diligence. This would end the anomaly that newly discovered evidence proving or strongly tending to prove the defendant's innocence is not generally a ground for obtaining a new trial unless the evidence is discovered within a stated short period or was deliberately suppressed by the state, whereas, for example, a defendant who has voluntarily confessed guilt can obtain collateral relief on a plea that the court erred in finding full compliance with Miranda. See Bator, supra note 15 , at 509 . In this way the $A B A$ Report recognizes how invalid the obeisance to "constitutional" claims has become.

885 WiLliston, ConTracts § 678, at 239 (3d ed. 1961).

89 ABA REPORT, supra note 14 , at 88.

90304 U.S. 464 (1938). 
doctrine of substantive law into the courtroom. ${ }^{91}$ At that stage the defendant's constitutional right is to have a full and fair opportunity to raise his claims on trial and appeal and the assistance of counsel in doing so. There is no need to find a "waiver" when the defendant or his counsel has simply failed to raise a point in court, since the state has not deprived him of anything to which he is constitutionally entitled. ${ }^{92}$

If the only available choices were to preclude collateral attack in all cases where the issue was or could have been raised at trial and on appeal except in the four special situations heretofore enumerated, or to allow it under the scant limitations provided in the ABA Report, the former would be preferable. But, as indicated, I would also allow an exception to the concept of finality where a convicted defendant makes a colorable showing that an error, whether "constitutional" or not, ${ }^{03}$ may be producing the continued punishment of an innocent man.

\section{IV}

Before going further I should clarify what I mean by a colorable showing of innocence. I can begin with a negative. A defendant would not bring himself within this criterion by showing that he might not, or even would not, have been convicted in the absence of evidence claimed to have been unconstitutionally obtained. Many offenders, for example, could not be convicted without the introduction of property seized from their persons, homes or offices. On the other hand, except for the unusual case where there is an issue with respect to the defendant's connection with the property, such evidence is the clearest proof of guilt, and a defendant would not come within the criterion simply because the jury might not, or even probably would not, have convicted without the seized property being in evidence. Perhaps as good a formulation of the criterion as any is that the petitioner for collateral attack must show a fair probability that, in light of all the evidence, including that alleged to have been illegally admitted (but with due regard to any unreliability of it) and evidence tenably claimed to have been wrongly excluded or to have become available only after the trial, the trier of the facts would have entertained a reasonable doubt of his guilt. ${ }^{94}$

91 The fountainhead of this error is Fay v. Noia, 372 U.S. 391, $439-40$ (1963).

92 Sunal v. Large, 392 U.S. 174, $177-78$ (1947).

93 See note 87 supra.

94 For an example that would have met this criterion if it had arisen by way of collateral attack, see United States v. Miller, 411 F.2d 825 (2d Cir. 1969)-one of the half dozen cases where, in eleven years of judicial experience, $I$ entertained real doubt about a defendant's guilt. On the new trial the defendant testified (as he had not on the first) and was acquitted. 
As indicated, my proposal would almost always preclude collateral attack on claims of illegal search and seizure. This is in sharp contrast to the decision in Kaufman $v$. United States, ${ }^{95}$ where the Supreme Court adopted the view of a minority of the courts of appeals. ${ }^{96}$ Here I am merely following a trail blazed some years ago by Professor Amsterdam, ${ }^{97}$ who surely cannot be accused of lack of sympathy for the criminal defendant. He urged that, subject to certain minor qualifications, ${ }^{98}$ society not only has no interest in the collateral enforcement of a claim to suppression of illegally obtained evidence but "has the strongest sort of interest against its enforcement." 99 So far as the defendant is concerned, the exclusionary rule is a bonanza conferring a benefit altogether disproportionate to any damage suffered, not so much in his own interest as in that of society. ${ }^{100}$ I cannot do better than to quote: "The rule is unsupportable as reparation or compensatory dispensation to the injured criminal; its sole rational justification is the experience of its indispensability in 'exert[ing] general legal pressures to secure obedience to the Fourth Amendment on the part of ... . law enforcing offcers.' "101 "As the exclusionary rule is applied time after time, it seems that its deterrent efficacy at some stage reaches a point of diminishing returns, and beyond that point its continued application is a public nuisance."102 And "if there is one class of cases that I would hazard to say is very probably beyond the point of diminishing returns, it is the class of search and seizure claims raised collaterally. For, so far as the law enforcement officer or the prosecutor is con-

95994 U.S. 217 (1969).

$96 \mathrm{Id}$. at $220-21 \mathrm{nn} .3 \& 4$.

97 Amsterdam, supra note 15, at 378 .

88 These are considered in an elaborate footnote, $i d$. at 391-92. I would add the rare case where the defendant's connection with the seized evidence was tenuous and the other evidence was thin.

99 Id. at 388.

100 See United States v. Dunnings, 425 F.2d 836, 840 (2d Cir. 1969). While "guilty defendants . . . are entitled to have the integxity of their persons and homes protected," Griffiths, Ideology in Criminal Procedure, or a Third Model of the Criminal Process, 79 YALE L.J. 359, 385 (1970), in Hohfeldian theory the consequence of this should be an action against the transgressor, not immunity from effective prosecution. The Supreme Court has consistently stressed that "the exclusionary rule . . . is calculated to prevent, not to repair," Elkins v. United States, 364 U.S. 206, 217 (1960). See also Linkletter v. Walker, 381 U.S. 618, 636-37 (1965).

101 Amsterdam, supra note 15, at 388-89. The inner quotation is from Mr. Justice Frankfurter's dissent in Elkins v. United States, 364 U.S. 206, 235 (1960). The efficacy of the exclusionary rule as a deterrent has been questioned in a remarkable article in this Review. Oaks, Studying the Exclusionary Rule in Search and Seizure, 37 U. CrI. L. REv. $665(1970)$.

102 Amsterdam, supra note 15 , at 389. 
cerned, the incidence of such cases is as unforeseeable as the flip of a coin; the option to raise the claim directly lies solely with the defense."103

I find no adequate answer in the majority opinion in Kaufman $v$. United States to these arguments, which Mr. Justice Black recounted in dissent with characteristic vigor and persuasiveness. ${ }^{104}$ The majority compendiously tells us that "adequate protection of constitutional rights relating to the criminal trial process requires the continuing availability of a mechanism for relief."105 This gives everything but the why. If a defendant represented by counsel has had one full and fair opportunity to raise a search and seizure claim, why is there any more need for continuing possibility to litigate this issue than any other? We are instructed that "[t]he availability of post-conviction relief serves significantly to secure the integrity of proceedings at or before trial and on appeal." 106 If "integrity" is being used in its sense of a "quality or state of being complete or undivided," just the opposite is true. I suppose the word is being used in its other sense of "utter sincerity, honesty, and candor," but even so the conclusion is hard to accept. As Mr. Justice Harlan has observed, Kaufman seems to rest on the idea that "the threat of habeas serves as a necessary additional incentive for trial and appellate courts throughout the land to conduct their proceedings in a manner consistent with established constitutional standards."107 This is an exceedingly serious indictment of the lower federal courts, for which I perceive no adequate factual basis. With today's awareness of constitutional rights, flagrant cases of police misconduct in search and seizure will rarely escape detection and correction in the trial or appellate process, even with the most slothful of defense counsel and the most careless of judges. The non-frivolous fourth amendment cases likely to give rise to collateral attack are those near the borderline, presenting hard questions of the meaning or application of Supreme Court decisions. Yet these are the cases where the deterrent function of the exclusionary rule is least important, ${ }^{108}$ and the argument for limiting collateral attack to instances, almost never present

$103 \mathrm{Id}$. at 390.

104394 U.S. at 231-42.

$105 \mathrm{Id}$. at 226.

$106 I d$. at 229.

107 Desist v. United States, 394 U.S. 244, 262-63 (1969) (dissenting opinion).

108 See H.J: Friendly, Benchararks 260-61 (1967), suggesting that even at trial the exclusionary rule should be limited to exclusion of "the fruit of activity intentionally or flagrantly illegal." 
in search and seizure, where constitutional error may have led to the conviction of an innocent man is the strongest. ${ }^{109}$

Another type of claim, certain to be a prodigious litigation breeder, concerning which I would forbid collateral attack in the absence of a colorable showing of innocence, consists of cases arising under Miranda v. Arizona.110 Consider, for example, one of the knottiest problems in the application of that case, namely, whether questioning by law enforcement officers without the Miranda warnings took place "after a person has been taken into custody or otherwise deprived of his freedom of action in any significant way."111 Almost all defense lawyers, indeed many defendants themselves, must be aware of the Supreme Court's new requirements about questioning in the station house. But suppose the lawyer does not know that Miranda may apply prior to the defendant's arrival there, or that he does not correctly understand what the field of application is, or that a court properly seized of the problem has held Miranda to be inapplicable and this is arguably wrong under existing or later decisions. This is generally not "the kind of constitutional claim that casts some shadow of doubt" upon the defendant's guilt. ${ }^{112}$ The mere failure to administer Miranda warnings in on-the-scene questioning creates little risk of unreliability, and the deterrent value of permitting collateral attack goes beyond the point of diminishing returns for the same reasons developed in Professor Amsterdam's discussion of search and seizure. I would take the same view of collateral attack based on claims of lack of full warnings or voluntary waiver with respect to station-house questioning where there is no indication of the use of methods that might cast doubt on the reliability of the answers.

The confession involuntary in the pre-Miranda sense helps to ilIustrate where I would draw the line. In a case where the prosecution had no other substantial evidence, as, for example, when identifica-

109 The Developments Note, supra note 9, at 1064-66, would justify Kaufman on the basis that the petitioner had not succeeded in having his claim considered on his appeal, and would limit the decision accordingly. Although appellate counsel had evidently thought the point too lacking in merit to raise, Kaufman himself had brought the matter to the attention of the court of appeals, 394 U.S. at $220 \mathrm{n.3}$, but that court did not discuss it. See 350 F.2d 408 (8th Cir. 1965) and 394 U.S. at 220 n.3. There is reason to think that Mr. Justice Brennan would accept the proposed limitation. See 394 U.S. at $227 \mathrm{n.8}$ and the quotation from Judge Wright's dissent in Thornton v. United States, 368 F.2d 822, 831 (D.C. Cir. 1966), at 394 U.S. 230-31. Cf. Kapatos v. United States, - F.2d - (2d Cir. 1970). My position is that opportunity to appeal should be enough.

110384 U.S. 436 (1966). I am not here considering the effect of 18 U.S.C. $\$ 3501$ (1964). 111384 U.S. at 444.

112 Kaufman v. United States, 394 U.S. 217, 242 (1969). See Johnson v. New Jersey, 384 U.S. 719, 730 (1966). 
tion testimony was weak or conflicting and there was nothing else, I would allow collateral attack regardless of what happened in the original proceedings. Such a case fits the formula that considerations of finality should not keep a possibly innocent man in jail. I would take a contrary view where the state had so much other evidence, even though some of this was obtained as a result of the confession, ${ }^{113}$ as to eliminate any reasonable doubt of guilt.

Neither your patience nor mine would tolerate similar examination of the application of my proposal to all constitutional claims. Such soundings as I have taken convince me that in other contexts as well the proposal would fully protect the innocent, while relieving the courts of most of the collateral challenges with which they are now unnecessarily burdened.

\section{V}

Assuming that collateral attack by federal prisoners should be restricted as I have suggested, what should be done with respect to the far more numerous prisoners held by the states, in whose hands the maintenance of public order largely rests?114 The subject has two aspects: The first is whether any changes should be made with respect to federal habeas corpus for state prisoners. The second is whether, in formulating their own procedures, the states should do what they would deem appropriate in the absence of the likelihood of a federal proceeding or should allow collateral attack in every case where the eyes of the federal big brother may penetrate.

At first blush it might seem that to whatever extent collateral attack on criminal judgments should be restricted within a unitary system, it ought to be even more so when one system operates on the judgments of another. The case to the contrary rests primarily on the practical inability of the Supreme Court to correct "constitutional" errors in state criminal proceedings through the appellate process. ${ }^{115}$ There is, of course, no such impediment when the issue is an important rule of criminal procedure as contrasted to its application in a particular case. The attack on the New York procedure concerning confessions is a good illustration; ${ }^{116}$ although the decision chanced to be made in federal habeas corpus, it could have been made just as well when the issue had been presented eleven years earlier on di-

113 The paradigm is where a confession of homicide leads to the discovery of a body bearing pieces of the defendant's hair, nails or clothing, or of weapons covered with defendant's fingerprints.

114 See H.J. FrIENDLy, BENCHMARKs 243 \& n.40 (1967).

115 See text at note 68 supra.

116 Jackson v. Denno, 378 U.S. 368 (1964). 
rect review, ${ }^{117}$ and the problem would surely have again arisen in that form if the Jackson case had not come along. Almost all the Court's most important decisions on criminal procedure, for example, those relating to equal protection for indigent defendants, ${ }^{118} \mathrm{com}$ ment on a defendant's failure to testify, ${ }^{119}$ the extension to the states of the exclusionary rule with respect to illegally seized evidence, ${ }^{120}$ confrontation, ${ }^{121}$ and custodial interrogation, ${ }^{122}$ have been made on direct review of state judgments. ${ }^{123}$

The argument for federal habeas corpus with respect to prisoners who have had a full and fair hearing and determination of their constitutional claims in the state courts thus must relate to two other categories of constitutional claims-disputed determinations of fact and the application of recognized legal standards. The contention is that only federal judges, with the protection of life tenure and supposedly greater knowledge of and sympathy for the Supreme Court's interpretations of the Constitution, can be trusted with the "final say" in such matters, although great deference to state factual determinations is required.124 While, if I were to rely solely on my own limited experience, I would think the case for the final federal say has been considerably exaggerated, ${ }^{125}$ I do not wish to add to the large amount of literature on this point. ${ }^{126}$

117 Stein v. New York, 346 U.S. 156 (1953).

118 Griffin v. Illinois, 351 U.S. 12 (1956); Douglas v. California, 372 U.S. 353 (1963).

119 Griffin v. California, 380 U.S. 609 (1965).

120 Mapp v. Ohio, 367 U.S. 643 (1961).

121 Pointer v. Texas, 380 U.S. 400 (1965).

122 Miranda v. Arizona, 384 U.S. 436 (1966).

123 Others, such as Gideon v. Wainwright, 372 U.S. 335 (1963), applying the requirement of appointed counsel to the states, and Malloy v. Hogan, 378 U.S. I (1964), applying the fifth amendment privilege against self-incrimination to them, have been made on review of state post-conviction attacks. The only significant decisions setting out new rules of criminal procedure (other than procedure in habeas itself) which were made on federal habeas for state prisoners appear to have been Jackson v. Denno, 378 U.S. 368 (1964), and Sheppard v. Maxwell, 384 U.S. 333 (1966).

12428 U.S.C. $\$ 2254$ (d) (1964).

125 My observation of the work of the excellent state courts of New York, Connecticut and Vermont does not suggest that federal determination of such questions is notably better. In the vast majority of cases we agree with the state courts, after a large expenditure of judges' and lawyers' time. In the few where we disagree, I feel no assurance that the federal determination is superior. When $I$ am confident that the issue has received real attention and the state trial and appellate judges have been in accord among themselves, I see no sufficient reason to elevate my views over theirs in a close case. See United States ex rel. Romeo v. McMann, 418 F.2d 860, 866 (2d Cir. 1969) (concurring opinion). The main difficulty is when one cannot be sure that the state courts, or at any rate the state appellate courts, have focused on the issue. Greater writing of opinions, however brief and informal, would alleviate the problem.

128 See, e.g., Bator, supra note 15; Brennan, Some Aspects of Federalism, 39 N.Y.U.L. REv. 945 (1964); Hart, Foreword: The Time Chart of the Justices, The Supreme Court, 
Assuming the final federal say is here to stay, is there any way to accelerate. it and thereby avoid the upsetting of a conviction by a federal court when the state can no longer conduct a retrial? One way would be to route appeals from state criminal decisions, whether on direct or on collateral attack, to a federal appellate tribunaleither the appropriate court of appeals or a newly created court $t^{127}$ and preclude federal habeas corpus as to issues for which that remedy is available. Although a number of different models could be visualized, one possibility would be this: After a state conviction or denial of post-conviction attack had become final, in those cases where the attack was not upon the constitutionality of a state rule but upon state fact-finding or application of a federal constitutional rule, ${ }^{128}$ a petition for review would lie not to the Supreme Court but to the federal appellate court. ${ }^{129}$ The standard for granting such review would be quite different from the Supreme Court's on certiorari. It would be more like what the courts of appeals now apply with respect to certificates of probable cause in state prisoner cases-not whether the issue was important to the law but whether the appeal raised a substantial claim of violation of constitutional rights. The criterion for such appellate review would thus be considerably more liberal than I have proposed with respect to collateral attack within a unitary system. When a prisoner had failed to seek such review, or the appellate court had declined to grant it or had decided adversely, federal habeas corpus with respect to any issue that could have been so presented would be foreclosed, except for those cases where I would preserve collateral attack within a unitary system, and for

1958 Term, 73 HARv. L. REv. 84, 104 (1959); Reitz, Federal Habeas Corpus: Impact of an Abortive State Proceeding, 74 HARv. L. REv. 1315 (1961); Reitz, Federal Habeas Corpus: Postconviction Remedy for State Prisoners, 108 U. PA. X. REv. 461 (1960); Wright \& Sofaer, supra note 24; Developments Note, supra note 9.

127 One argument against utilizing the existing courts of appeals is that they are already overburdened. But many of the cases that would come to them under this proposal reach them now in federal habeas, either on applications for certificates of probable cause or for full-dress argument when such certificates have been granted. Considerations in favor of utilizing the existing courts are their geographical convenience, their greater knowledge of relevant state procedures and the quality of particular state judges, the difficulty in manning a specialized court, and the historic prejudice against tribunals of specialized jurisdiction. On the other side are the possibly greater acceptability of review by a "super court" to the highest courts of the states, see note 130 infra, and the uniformity that would result from review by such a court.

128 Alternatively, a petition to review in the federal appellate court would be required whenever the attack was based on procedural due process, including the selectively incorporated provisions of the Bill of Rights, as distinguished from substantive attack on a state criminal statute, e.g., as violating the first amendment.

129 Any legislation would include familiar procedures for transfer where application had been made to the wrong court. 
them only if the state had not provided a means for collateral attack in its own courts. Where it did, the prisoner must use it, and final state decisions would be reviewable in the same manner as proposed for state decisions on direct appeal.

Such a scheme would preserve the original understanding that judgments of the highest courts of the states are to be re-examined only by a federal appellate court rather than at nisi prius. ${ }^{130}$ More important, it would force the prisoner to use his federal remedy while the record is reasonably fresh and a retrial is practical. While the proposal depends on the state court's having made an adequate record and findings, the court of appeals could remand where it had not. Perhaps the most serious objection is that unless review by the Supreme Court were severely restricted, or stays in non-capital cases pending application for such review were forbidden, insertion of an appeal to a lower federal appellate tribunal would further postpone the date when a convicted state prisoner begins to serve his sentence. I advance the suggestion only as one warranting discussion, to take place in the larger context of whether the time has not come when the Supreme Court should be relieved of some of its burdens.

Whether there is merit in this proposal or not, I would subject federal habeas for state prisoners to the same limitations that I have proposed for federal prisoners. With the four exceptions noted at the outset, I see no sufficient reason for federal intervention on behalf of a state prisoner who raised or had an opportunity to raise his constitutional claim in the state courts, in the absence of a colorable showing of innocence. It is sufficient if the benefit of fact-finding and the application of constitutional standards by a federal judge is available in cases of that sort.

Assuming that nothing happens on the federal scene, whether through congressional inertia or otherwise, what should the states do with respect to their own systems for collateral attack on convictions? In my view, if a state considers that its system of post-conviction remedies should take the lines I have proposed, it should feel no obligation to go further ${ }^{131}$ simply because this will leave some cases where the only postconviction review will be in a federal court.

I realize this may seem to run counter to what has become the received wisdom, even among many state judges and prosecutors.

130 On the other hand, some judges with whom I have discussed this believe that the highest state courts would find it even more offensive to have their constitutional decisions reviewed by the existing federal courts of appeals; if so, this might argue that a new "super court" would be preferable if this procedure is to be used at all. See note 127 supra.

131 This is recognized in the ABA REPORT, supra note 14 , at 86. 
One part of the angry reaction of the Conference of State Chief Justices to Brown v. Allen ${ }^{132}$ was the recommendation that:

State statutes should provide a postconviction process at least as broad in scope as existing Federal statutes under which claims of violation of constitutional right asserted by State prisoners are determined in Federal courts under Federal habeas corpus statutes. ${ }^{133}$

The recommendation for broadening state post-conviction remedies was doubtless salutary in 1954 when many states had few or none. ${ }^{134}$ As my remarks have made evident, I recognize a considerable area for collateral attack; indeed, I think there are circumstances, such as post-trial discovery of the knowing use of material perjured evidence by the prosecutor or claims of coercion to plead guilty, where failure to provide this would deny due process of law. ${ }^{135} \mathrm{My}$ submission here is simply that when a state has done what it considers right and has met due process standards, it should not feel obliged to do more merely because federal habeas may be available in some cases where it declines to allow state collateral attack.

The argument against this is that making the state post-conviction remedy fully congruent with federal habeas for state prisoners (1) will economize judicial time, (2) will reduce state-federal conflict, and (3) will provide a record on which the federal judge can act. Except for the few cases where pursuit of the state remedy will result in a release, absolute or conditional, the first argument rests on the premise that many state prisoners will accept the state's adverse judgment. I know of no solid evidence to support this; ${ }^{136}$ my impression is that prisoners unsuccessful in their post-conviction applications through the state hierarchy almost inevitably have a go at federal habeas, save when their sentences have expired. In the great majority of cases the job simply has to be done twice. Pleasant though it is for federal judges to have the task initially performed by their state

132344 U.S. 443 (1953).

133 H.R. REP. No. 1293, 85th Cong., 2d Sess. 7 (1958).

134 See the 1958 report of the Burton Committee, quoted in part in Case v. Nebraska, 381 U.S. 336, 339 (1965) (Clark, J., concurring).

135 Cf. Mooney v. Holohan, 294 U.S. 103 (1934); Young v. Ragen, 337 U.S. 235 (1949).

136 Mr. Justice Clark said in Case v. Nebraska, 381 U.S. 336, 340 (1945) (concurring opinion), that it was reported that federal applications from state prisoners in Illinois "dropped considerably after its [post-conviction] Act was adopted." One would expect that to happen while the new state remedies were being exhausted; whether the decrease was other than temporary is another matter. The district courts for Illinois had 286 state prisoner petitions in the year ended June 30, 1969. 1969 ANNUAL REPORT, supra note 5 , at 211. The nationwide figures cited above, see text and note at note 5 supra, show constant increases despite greatly expanded state post-conviction remedies. 
brethren, the over-all result is to increase the claims on judicial and prosecutorial time. The conflict that would otherwise exist is avoided only in the rare instances where the state itself grants release and, more important, in cases where it finds the facts more favorably to the prosecution than a federal judge would do independently, but the latter respects the state determination. ${ }^{137}$ This last is also the real bite in the point about record making. ${ }^{138}$ It is, of course, somewhat ironic that after federal habeas has been justified in part on the basis of the superiority of fact determinations by the federal judge, the states should be urged to elaborate their post-conviction remedies so as to enable him to avoid the task. Moreover, conflict is even more acrid when a federal judge rejects not simply a state determination after trial and appeal but also its denial of post-conviction relief. ${ }^{139}$ It should be remembered also that my proposal contemplates state postconviction record making when there is new evidence that was not available at trial, and that the state trial or pre-trial proceedings will contain a record whenever the point was then raised. The problem areas would thus largely be cases where the point could have been but was not raised at the state trial..$^{140} \mathrm{Be}$ all this as it may, such considerations are for the state to weigh against what it may well consider an excessive expenditure of effort in dealing with collateral attack. While the immediate result of a state's failure to provide the full panoply of post-conviction remedies now available in federal habeas would be an increase in the burdens on the federal courts, this might afford the impetus necessary to prod Congress into action.

137 Presumably this is what Mr. Justice Brennan meant in saying, in Case v. Nebraska, 381 U.S. 336, 345 (1945) (concurring opinion), "Greater finality would inevitably attach to state court determinations of federal constitutional questions, because further evidentiary hearings on federal habeas corpus would, if the conditions of Townsend v. Sain were met, prove unnecessary."

138 Note Mr. Justice Brennan's statement in Case v. Nebraska, 381 U.S. 336, 345 (1945), that, "nonmeritorious claims would be fully ventilated, making easier the task of the federal judge if the state prisoner pursued his cause further."

139 For an example see United States ex rel. Stephen J.B. v. Shelly, 430 F.2d 215 (2d Cir. 1970), where a district judge, without hearing any further evidence, annulled the unanimous holdings of $13 \mathrm{New}$ York judges, culminating in an opinion by the Court of Appeals, People v. Stephen J.B., 23 N.Y.2d 611, 246 N.E.2d 344, 298 N.Y.S.2d 489 (1969), on a close question relating to Miranda-and this in a case where the defendant had been placed on probation and, because he was a juvenile, his conviction had no civil consequencesl

140 As to these I would favor an amendment to 28 U.S.C. \& 2254 (1964) which would make it clear that the rule of Henry v. Mississippi, 379 U.S. 443 (1965), applies to federal habeas for state prisoners, without any of the doubts now existing, either there or on direct appeal, in regard to the need of personal participation by the defendant in feasance or nonfeasance by his attorney. See Sandalow, Henry v. Mississippi and the Adequate State Ground: Proposals for a Revised Doctrine, 1965 Sup. Cr. Rev. 187. 
The final question is whether this or any other proposal for reform is vain imagining since any change in the Supreme Court's construction of the Habeas Corpus Act of 1867 would be unconstitutional.

Taking federal prisoners first, I recognize the existence of some cases where, quite apart from the suspension clause, refusal to provide post-conviction relief would be a denial of due process. My proposal goes well beyond these; it takes care of all challenges to the validity of the criminal process itself including lack of counsel, of all cases where the defendant poses constitutional claims he could not practically have advanced before conviction or where proper procedures were not provided for doing this, of constitutional claims resulting from changes in the rules of the game to whatever extent the Supreme Court indicates, and, finally, of all other constitutional claims subject only to a colorable showing of innocence. The question is whether limitation of habeas for federal prisoners to these cases, plainly consistent with due process as I consider it to be, runs afoul of the framers' mandate that:

The privilege of the Writ of Habeas Corpus shall not be suspended, unless when in Cases of Rebellion or Invasion the public Safety may require it. ${ }^{141}$

It can scarcely be doubted that the writ protected by the suspension clause is the writ as known to the framers, not as Congress may have chosen to expand it or, more pertinently, as the Supreme Court has interpreted what Congress did. ${ }^{142}$ The argument against such a moderate turning back from these decisions as I have proposed thus must rest on the extended historical exercise in Fay v. Noia, culminating in the statement:

Thus, at the time-that the Suspension Clause was written into our Federal Constitution and the first Judiciary Act was passed conferring habeas corpus jurisdiction upon the federal judiciary, there was respectable common-law authority for the proposition that habeas was available to remedy any kind of governmental restraint contrary to fundamental law. ${ }^{143}$

It has now been shown with as close to certainty as can ever be ex-

141 U.S. ConsT. art. I, \& 9, cl. 2.

142 A contrary view is taken, quite unconvincingly, in Developments Note, supra note 9 , at 1269 .

143372 U.S. at 405. 
pected in such matters ${ }^{144}$ that, despite the "prodigious research" evidenced by the Noia opinion, the assertion that habeas as known at common law permitted going behind a conviction by a court of general jurisdiction is simply wrong. The very historians cited in the opinion disagree with any such conclusion. ${ }^{145}$ Bushell's Case, ${ }^{146}$ the only authority cited that gives even slight support to the thesis espoused in the elaborate dictum, is wholly inadequate to sustain the view that English courts used the writ to penetrate convictions of felony and treason and seek out violations of Magna Carta. ${ }^{147}$

While I do not share the anticipations of some that the Burger Court will indulge in wholesale overrulings in the field of criminal procedure, it should not feel bound by an historical essay, that now appears to have been clearly erroneous, on a point not in issue and as to which the Court consequently did not have the benefit of an adversary presentation. ${ }^{148}$ It is quite unrealistic to suppose that the other Justices had the time or, in view of the irrelevance of the discussion, the incentive to subject this historical essay to critical analysis, and one would hope that even its distinguished author might be willing to reconsider it in the light of what disinterested research has shown. Indeed, the last relevant pronouncement of the Warren Court on the subject seemed to recognize that the Act of 1867 "expanded" the writ beyond its status at common law, and that it is Congress that "has determined that the full protection of their [federal and state prisoners'] constitutional rights requires the availability of a mechanism for collateral attack." 140 What Congress has given, Congress can partially take away.

I likewise do not quail before another statement ${ }^{150}$ that if the provision in 28 U.S.C. $\$ 2255$ (1964) with respect to repetitive applications by federal prisoners were "construed to derogate from the

144 Oaks, supra note 13 , at 456-68.

145 Id. at 459 \& n.47. See also Rubinstein, Habeas Corpus as a Means of Review, 27 MoD. L. REv. 322, 326 (1964): "Superior and other common law courts enjoy, therefore, an almost complete immunity from review on habeas corpus."

146124 Eng. Rep. 1006 (C.P. 1670).

147 As Professor Oaks has pointed out, any such reading of the opinion in Bushell's Case would bring it into conflict with three fundamental principles of seventeenth and eighteenth century habeas corpus law-that a general return that the prisoner had been committed for treason or felony was sufficient; that petitioners were forbidden to challenge the truth of particulars set out in the return; and that once a person had been convicted by a superior court of general jurisdiction, a court seized of a habeas petition could not go behind the conviction for any purpose other than to verify the jurisdiction of the convicting court. Oaks, supra note 13, at 468.

148 Id. at 458.

140 Kaufman v. United States, 394 U.S. 217, 221, 228 (1969).

150 Sanders v. United States, 373 U.S. I, II-12 (1963). 
traditional liberality of the writ of habeas corpus," it "might raise serious constitutional questions." For the reason just indicated I do not regard the questions as serious, but even if they were, Congress has not merely the right but sometimes the duty to raise such questions. To seek legislative consideration of a proposal to cut back on the Supreme Court's expansive construction of the Act of 1867 but leave the Great Writ with a much broader scope than anything of which the framers could have dreamed would not be asking nearly so much as President Roosevelt did in his famous statement that Congress should not "permit doubts as to constitutionality, however reasonable, to block the suggested legislation." 151 It is surely not irrelevant in this context that the valiant champion of every syllable of the Constitution would confine collateral attack to a claim by a defendant which "casts some shadow of doubt upon his guilt."152

If my proposal with regard to federal prisoners is thus constitutional, the same is a fortiori true concerning federal habeas for state prisoners. ${ }^{153}$ And the suggestion that the states need go no further with respect to their own post-conviction procedures is even more clearly so. The suspension clause applies only to the federal government and, while complete denial of post-conviction remedies by a state would violate the due process clause of the fourteenth amendment in some cases, nothing in the Constitution requires a state to allow collateral attack simply because Congress has authorized federal habeas corpus to challenge the state conviction. ${ }^{154}$ Although the state is bound by the supremacy clause to honor all constitutional guarantees, it is not bound to honor them more than once.

My submission, therefore, is that innocence should not be irrelevant on collateral attack even though it may continue to be largely so on direct appeal. To such extent as we have gone beyond this, and it is an enormous extent, the system needs revision to prevent abuse by prisoners, a waste of the precious and limited resources available for the criminal process, and public disrespect for the judgments of criminal courts.

\footnotetext{
15179 Cong. Rec. 13449 (1935), cited in D. Morgan, Congress and the Constitution 6 (1966).

152 Kaufman v. United States, 394 U.S. 217, 235 (Black, J., dissenting).

153 See Pollack, supra note 33, at 63 \& n.73. But see Developments Note, supra note 9, at 1272-74. I indicate no view on the current status of Ex parte Bollman, 8 U.S. (4 Cranch) 75 (1807), discussed in Paschel, The Constitution and Habeas Corpus, 1970 DURE L.J. 605.

154 Case v. Nebraska, 381 U.S. 336 (1965), does not decide otherwise, although on the facts-a claim of a coerced guilty plea-denial of a post-conviction remedy could well have violated due process. See Sandalow, stupra note 140, at 210-15.
} 